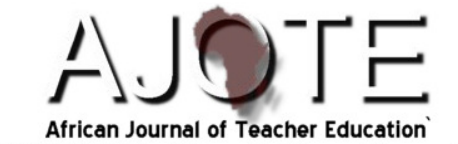

ISSN: 1916-7822 A Journal of Spread Corporation

Volume 1 No. $1 *$ Pages $34-47 *$ October 2010

\title{
FACTORS INFLUENCING EARLY CHILDHOOD DEVELOPMENT TEACHERS' MOTIVATION IN THIKA DISTRICT, KENYA
}

\author{
Mary N. Ndani, PhD. \\ Kenyatta University, Nairobi-Kenya \\ ndanimn@yahoo.com
}

\author{
Elishiba N. Kimani, PhD. \\ Kenyatta University, Nairobi-Keny; \\ elishibakimani@yahoo.com
}

\begin{abstract}
Early Childhood Development (ECD) centres comprise one of the immediate social and physical environments influencing children's development, that Bronfenbrenner $(1986,1989)$ terms Microsystems. The Microsystems are made up of personal qualities of the people therein (particularly teachers) and the physical environments. In order for ECD centres to provide the necessary conditions for children's holistic development, teachers should be well motivated and physical facilities conducive for working and learning. The sample of the study was comprised of 40 ECD centres and 46 ECD teachers. Preschool Teachers' Motivation Questionnaire and an observation checklist were used to collect the primary data. Secondary data were obtained from various records in the ECD centres. Among the key findings was the revelation that the motivation levels of more than $50 \%$ of the teachers were below average. The study recommended that the Ministry of Education and communities work together to improve ECD teachers' terms and conditions of service as well as the learning/teaching environment.
\end{abstract}




\section{Factors Influencing Early Childhood Development Teachers' Motivation in Thika District, Kenya}

\section{Background to the Study}

The need for a holistic development of children is appreciated all over the world. Consistently, United Nations' Convention on the Rights of the Child (UNCRC, 1989), African Charter on Rights and Welfare of the Child (OAU, 1990) and the Government of Kenya (Republic of Kenya, 1998) recognize the right of every child to a standard of living adequate for its physical, mental, spiritual, moral and social development. This implies that care givers should provide adequate and appropriate care to children, since developmental deficiencies that occur during this stage are difficult to reverse (Pipes \& Trahms, 1993).

Unfortunately, increased urbanization, introduction of formal education, the universal use of the money economy and the multiplicity of the roles of mothers, pose challenges in the use of the traditionally effective childcare systems. Consequently, Early Childhood Development (ECD) centres have been accepted by contemporary societies worldwide as an alternative child care system. These centres comprise one of the immediate physical and social environments experienced by young children that Bronfenbrenner (1986/1989, cited in Black and Puckett 1996) terms Microsystems. The Microsystems are made up of the personal qualities of teachers, other caregivers and peers therein, as well as the quality of the physical environment to which the child is exposed. They also comprise of the activities, roles and interpersonal relationships experienced by the developing person, all of which have an influence on children's development. However, "evidence abound that the teacher is the most important single factor in determining what a school (ECD) experience will be like for children" (Read, Gardner and Mahler, 1993 p. 41).

Thus, creating conditions that motivate ECD teachers to initiate positive interactions with children and a physical environment that is conducive both to teachers' work and children's development is essential. To create these conditions, ECD centre communities who sponsor about $70 \%$ of the ECD centres in Kenya (Republic of Kenya, 1998) need to participate to address what Herzberg, Mausner, \& Snyderman (1959) termed 'hygiene' factors or 'job context' needs. These include physical working conditions, salary, benefits, job security, and interpersonal relations.

Demonstrating the importance of hygiene factors, research (Howes, Smith \& Clanlinsky 1995; Love, Ryre \& Faddis, 1992; and Essa, 2003) has reported that preschool teachers whose 'hygiene' needs are satisfied, become warm, sensitive and nurturing. The teachers in these studies showed great responsiveness, gave encouragement to children and used less negative disciplinary techniques. As a result, children developed positive emotional adjustments and their cognitive, language and social skills were enhanced. Additionally, the children displayed fewer behavioral problems and became socially competent. Ultimately, the amount of adult interaction with children became greater and more beneficial, and children had friendlier interactions with peers.

These positive child outcomes clearly demonstrate the need to motivate teachers. The key factors influencing ECD teacher motivation therefore needed to be investigated in order to guide 
communities in areas where they need to concentrate their efforts. This was important because most preschool teachers reportedly worked in what Herzberg described as an "unhealthy psychological work environment", including unclear terms and conditions of service (Makoti, 2005), and low irregular salary averaging Ksh.2000 a month (Ngome, 2002, Waithaka, 2003 and Makoti, 2005). Heavy workload was also considered to be a de-motivating factor as Ngome (2002) found unmanageable pupil enrollment to contribute to the 54.56 percent rate of preschool teacher attrition.

In addition, studies had shown that most centers lacked the necessary facilities, equipment and materials that would promote teacher motivation and holistic development of children. According to Ngome (2002), most public centers supported unfriendly work conditions characterized by windowless, rough mud walled and floored classrooms, and others that were iron-sheet walled and roofed. In such classrooms, temperatures went very high or very low, ventilation was inadequate, dust was a problem and children were easily distracted. Most of these classrooms were also congested. (Gakii, 2003 and Ng'asike, 2004). Further, findings of the Ministry of Education Science and Technology (MOEST, 1999) had revealed that on average, preschools even within primary school compounds were worse off than their lower primary counterparts, in terms of provision and appropriateness of facilities.

\section{Statement of the Problem}

As illustrated in the background, the need for care that would lead to the holistic development of the child is appreciated globally and a corresponding right granted (UNCRC, 1989, OAU 1990 and Republic of Kenya, 1998). To secure this right the conditions necessary for optimal development of children need to be secured within children's Microsystems among which are ECD centres (Bronfenbrenner 1986/1989, cited in Black and Puckett 1996). To do this, communities need to focus on two important aspects of the preschool Microsystems: the teachers and the physical learning environments. In particular, the teachers have been found to play a critical role in children's development (Read, Gardner and Mahler, 1993; Howes, Smith \& Clanlinsky, 1995; and Essa, 2003). The effectiveness of the teachers on the other hand depends on the existing levels of motivation.

Unfortunately, research findings in Kenyan ECD centres have revealed some prevalent unfavorable conditions for teacher motivation. To enable ECD communities to prioritize the areas that require urgent intervention in ensuring the conditions necessary for optimal development of children, there was a need to establish the extent to which preschool teachers were motivated, as well as the factors that motivated and those that de-motivated them. This was the gap that this study was set to fill.

\section{Research Objectives}

The objectives of the study were to:

i. establish preschool teachers' motivation levels.

ii. explore preschool teachers' motivators and de-motivators.

iii. come up with recommendations for policy action and interventions.

\section{Conceptual Framework}

Bronfenbrenner (1986) advocates that the physical facilities, equipment and materials present in the environment in which children live, and the interpersonal relationships of the persons with 
whom they interact, influence children's development. ECD teachers are among the most important persons in children's interpersonal relationships. One of the most important influences on the children's psychosocial environment therefore is the level of ECD centre teacher motivation.

Relevant strategies should therefore be geared towards motivating teachers and providing a child-friendly environment. Satisfying teachers' hygiene needs, including favourable terms and conditions of service, a manageable workload, 'good' remuneration as well as providing an adequate physical working environment is expected to result in motivating them (Herzberg, Mausner \& Snyderman, 1959). This, in turn, is likely to result in teachers becoming effective in stimulating and nurturing children, responding sensitively to their needs, encouraging them and using few negative disciplinary actions. Consequently, teachers would achieve the ultimate psychosocial development goals in children: the development of high cognitive and language skills, positive emotional adjustment and social competence. The relationships between these variables are illustrated in Figure 1.

Key:

Shaded area

Relationships between

the study variables.

Unshaded area

Expected teacher and

child outcomes not included in this study.

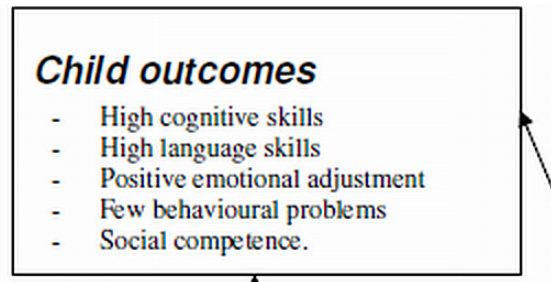

Interactive behaviour of motivated Teachers

- Warmth

- Nurturance

- Responsiveness

- Encouragement

- Little use of negative disciplinary action

- Stimulating

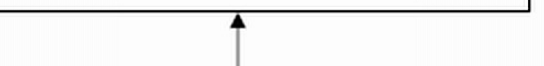

Teacher Motivation

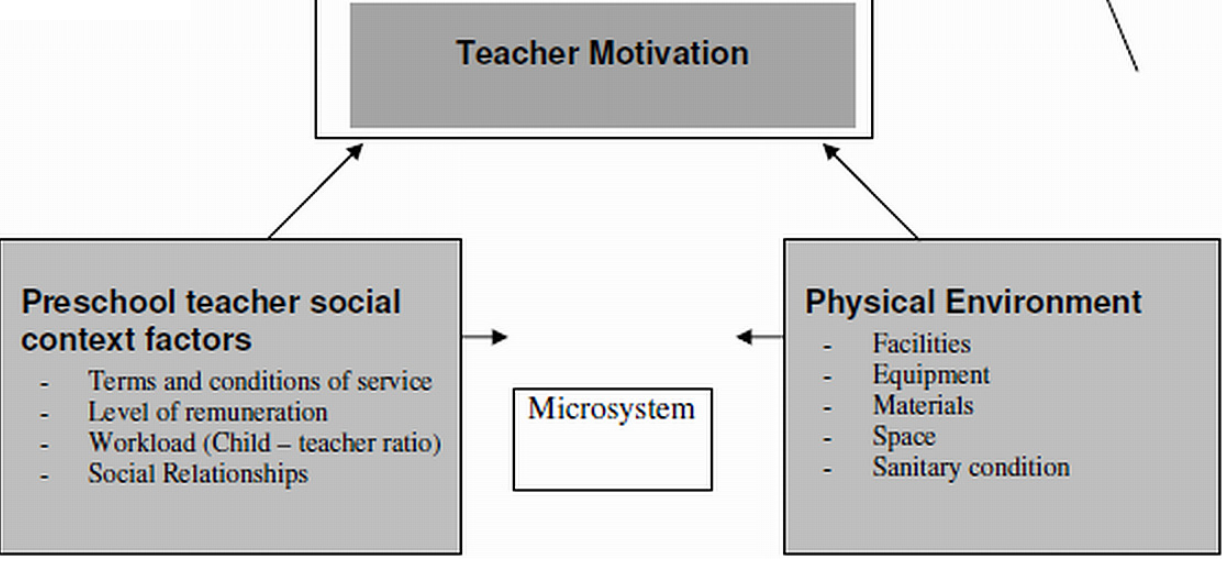

Figure 1: Conceptual Framework: Influences of Teacher Motivation 


\section{METHODOLOGY}

The methodology followed in this study is briefly described below under the sub-headings: research design, study locale, target population, sampling technique and sample size, research instruments and data analysis techniques.

\section{Research Design}

The study employed an ex-post-facto research design and yielded mainly descriptive data. The variables studied were as shown in Table 1.

\begin{tabular}{|l|l|}
\hline ECD teacher social context factors & \\
Terms and conditions of service & \\
Level of remuneration & \multirow{3}{*}{ Teacher motivation } \\
Workload (Child - teacher ratio) & \\
Social Relationships & \\
\cline { 1 - 2 } ECD physical environments & \\
Facilities & \\
Equipment & \\
Materials & \\
Space & \\
Sanitary condition & \\
\hline
\end{tabular}

\section{Table 1: Study Variables}

Independent variables consisted of ECD teacher social context factors and physical environments. The dependent variable was the level of teacher motivation.

\section{Study Locale}

The research was carried out in Thika District of Central Province, Kenya. The district was chosen because it encompassed the following characteristics:

1) Large geographical area;

2) High population, albeit unevenly distributed;

3) Pre-schools of the four categories of sponsorship: public, private, Local authority (LA) and faith led, or Religious Organizations (RO);

4) Varied economic potential and ecological zones, that is, Thika municipality, Ruiru and Juja zones with diverse residential areas ranging from upper middle class to informal settlements, high potential rural areas - comprising Kariara and Kigoro zones, moderately low agricultural potential zone of Mitubiri and the semi-arid zones of Kakuzi and Ithanga.

\section{Target Population}

The target population for the study consisted of all ECD centres and teachers in the district. According to the records, the district had a total of 764 preschools of which 390 were found in the identified participating zones. Out of the 390 pre-schools, communities sponsored 99, private 
individuals 189, Local Authorities 36 and Religious Organizations 66. The samples from this population and sampling techniques are discussed in the section below.

\section{Sampling Techniques and Sample Size}

Stratified random sampling with purposive selection of the strata and simple random sampling using the lottery technique were employed in the study. This was to ensure representation of all desired categories of strata; socio-economic potential (high and low zones), the geographical context (rural and urban), and the preschool sponsorship. Using these methods, a total of 40 preschools and 46 teachers were sampled. The number of sampled preschools per zone and category were as illustrated in Table 2.

Table 2: Number of sampled preschools per zone and category

\begin{tabular}{|l|l|l|l|l|l|}
\hline Zone & Public & Private & L.A & R.O. & $\begin{array}{l}\text { Total } \\
\text { Number of } \\
\text { schools }\end{array}$ \\
\hline Kariara & 1 & 1 & 1 & - & 3 \\
\hline Kigoro & 1 & 1 & 1 & - & 3 \\
\hline $\begin{array}{l}\text { Thika } \\
\text { municipality }\end{array}$ & 2 & 7 & - & 2 & 11 \\
\hline Ruiru & 2 & 6 & - & 1 & 9 \\
\hline Ithanga & 1 & - & 1 & 1 & 3 \\
\hline Kakuzi & 1 & 1 & - & 1 & 3 \\
\hline Mitubiri & 1 & 2 & - & - & 3 \\
\hline Juja & 2 & 2 & - & 1 & 5 \\
\hline Total & 11 & 20 & 3 & 6 & 40 \\
\hline
\end{tabular}

\section{Research Instruments}

The data were collected using Preschool Teachers' Motivation Questionnaire and the Preschool Physical Environment Check List. The instruments were constructed by the researchers. To check for consistency in their content, the split-half test of reliability was carried out. The relevant instruments analyzed for this purpose were administered to 10 teachers. Scores from even numbered items were correlated against scores obtained from odd numbered items. Data collected in the pilot study were analysed using Spearman's Correlation Coefficient at the significance level of alpha $=0.05$. The instrument was found to be reliable.

To ensure validity, expertise of two peers who were familiar with the study area was sought. These were asked to check whether the items in the instrument were viable to collect the intended data. Additionally, the researchers conducted all the study in person in order to ensure systematic validity. The data collected were analysed as discussed in the following section.

The level of preschool teacher motivation was measured using a six-point Likert scale. This scale was used to rate 19 motivation variables adapted from Herzberg's study. Teachers' level of motivation was obtained by calculating the mean Z-score. The statistic is a standard score with a 
mean score of zero (0) and a standard deviation of one (1). Using this statistic, a raw score above the mean attains a positive Z-score and that below the mean a negative Z-score (Orodho, 2004). Scores above the mean were therefore considered high and those below it low.

This statistic was also applied to the data on preschool physical environments. To get the average suitability of the environment, the scores of the different aspects were summed up and the Z-score of the totals obtained. Any score above the mean Z-score was taken as high, denoting suitable environments, while those below were considered low and therefore unsuitable environments.

\section{SUMMARY OF RESULTS AND RECOMMENDATIONS}

The study established that the preschool teachers' satisfaction levels were quite varied as shown in Table 3. Among the factors that ranked highly as satisfiers were: Teachers relationship with children, with a frequency of 43(93.5\%), their relationship with the community with $36(78.3 \%)$ and recognition received from the community for good work, which had 34(73.9\%). This suggests that social relationships were important in influencing teacher motivation.

TABLE 3: Preschool Teachers' Ranking of Motivation Factors

\begin{tabular}{|c|c|c|c|c|c|c|}
\hline \multirow[t]{2}{*}{ Motivation Factors } & NA & Dissatisf & $\begin{array}{l}\text { Fairly } \\
\text { D. }\end{array}$ & Neutral & $\begin{array}{l}\text { Fairly } \\
\text { S. }\end{array}$ & Satisfied \\
\hline & F.(\%) & F.(\%) & F.(\%) & F.(\%) & F.(\%) & F.(\%) \\
\hline $\begin{array}{l}\text { Teacher's relationship with } \\
\text { children. }\end{array}$ & $-(0.0)$ & $-(0.0)$ & $-(0.0)$ & $-(0.0)$ & $3(6.5)$ & $43(93.5)$ \\
\hline $\begin{array}{l}\text { Teacher's relationship with } \\
\text { the community. }\end{array}$ & $-(0.0)$ & $-(0.0)$ & $-(0.0)$ & $1(2.2)$ & $9(19.6)$ & $36(78.3)$ \\
\hline $\begin{array}{l}\text { Recognition received from } \\
\text { community for good work. }\end{array}$ & $-(0.0)$ & $2(4.3)$ & $1(2.2)$ & $-(0.0)$ & $9(19.6)$ & 34 (73.9) \\
\hline Age of children in class. & $-(0.0)$ & $3(6.5)$ & $7(15.2)$ & $-(0.0)$ & $6(13.0)$ & $30(65.2)$ \\
\hline $\begin{array}{l}\text { Number of hours worked } \\
\text { daily. }\end{array}$ & $-(0.0)$ & $4(8.7)$ & $6(13.0)$ & $-(0.0)$ & $8(17.4)$ & $28(60.9)$ \\
\hline $\begin{array}{l}\text { Teacher's relationship with } \\
\text { school management. }\end{array}$ & $4(8.7)$ & $-(0.0)$ & $2(4.3)$ & $-(0.0)$ & $15(32.6)$ & $25(54.3)$ \\
\hline Number of children in class & $-(0.0)$ & $5(10.9)$ & $9(19.6)$ & $-(0.0)$ & 9 (19.6) & $23(50.0)$ \\
\hline $\begin{array}{l}\text { Physical conditions of the } \\
\text { classroom }\end{array}$ & $-(0.0)$ & $3(6.5)$ & $6(13.0)$ & $-(0.0)$ & $16(34.8)$ & $21(45.7)$ \\
\hline Supply of teaching materials & $-(0.0)$ & $8(17.4)$ & $5(10.9)$ & $-(0.0)$ & $12(26.1)$ & $21(45.7)$ \\
\hline $\begin{array}{l}\text { Physical conditions of the } \\
\text { school }\end{array}$ & $-(0.0)$ & $4(8.7)$ & $5(10.9)$ & $-(0.0)$ & $19(41.3)$ & $18(39.1)$ \\
\hline $\begin{array}{l}\text { Societal expectation on } \\
\text { teacher's performance }\end{array}$ & $-(0.0)$ & $5(10.9)$ & $5(10.9)$ & $1(2.2)$ & $17(37.0)$ & $18(39.1)$ \\
\hline $\begin{array}{l}\text { Support the teacher gets from } \\
\text { the community }\end{array}$ & $2(4.3)$ & $3(6.5)$ & $4(8.7)$ & $-(0.0)$ & $20(43.5)$ & $17(37.0)$ \\
\hline $\begin{array}{l}\text { Parent's expectation of } \\
\text { children's performance }\end{array}$ & $3(6.5)$ & $1(2.2)$ & $6(13.0)$ & $-(0.0)$ & $19(41.3)$ & $17(37.0)$ \\
\hline
\end{tabular}


Mary N. Ndani \& Elishiba N. Kimani

\begin{tabular}{|l|l|l|l|l|l|l|}
\hline \hline $\begin{array}{l}\text { Effect of community on } \\
\text { Teachers' experience on } \\
\text { teaching }\end{array}$ & $3(6.5)$ & $2(4.3)$ & $\begin{array}{l}10 \\
(21.7)\end{array}$ & $6(13.0)$ & $13(28.3)$ & $\mathbf{1 2}(\mathbf{2 6 . 1})$ \\
\hline One's pay compared to others & $1(2.2)$ & $14(30.4)$ & $8(17.4)$ & $1(2.2)$ & $17(37.0)$ & $\mathbf{5}(\mathbf{1 0 . 9})$ \\
\hline Provision of house allowance & $\begin{array}{l}16 \\
(34.8)\end{array}$ & $\begin{array}{l}21 \\
(45.7)\end{array}$ & $3(6.5)$ & $1(2.2)$ & $2(4.3)$ & $\mathbf{3}(\mathbf{6 . 5})$ \\
\hline $\begin{array}{l}\text { Provision of retirement } \\
\text { benefits }\end{array}$ & $18(39.1)$ & $\begin{array}{l}20 \\
(43.5)\end{array}$ & $2(4.3)$ & $2(4.3)$ & $1(2.2)$ & $\mathbf{3}(\mathbf{6 . 5})$ \\
\hline Amount of salary received & $-(0.0)$ & $\begin{array}{l}21 \\
(45.7)\end{array}$ & $9(19.6)$ & $2(4.3)$ & $12(26.1)$ & $\mathbf{2}(\mathbf{4 . 3})$ \\
\hline $\begin{array}{l}\text { Status of preschool teachers in } \\
\text { Kenya }\end{array}$ & $-(0.0)$ & $\begin{array}{l}17 \\
(37.0)\end{array}$ & $16(34.8)$ & $1(2.2)$ & $10(21.7)$ & $\mathbf{2}(\mathbf{4 . 3})$ \\
\hline \multicolumn{1}{|c|}{ Aggregate } & $\mathbf{4 7}$ & $\mathbf{1 3 3}$ & $\mathbf{1 0 4}$ & $\mathbf{1 5}$ & $\mathbf{2 1 7}$ & $\mathbf{3 5 8}$ \\
$\mathbf{( 1 5 . 4 )}$ & $\mathbf{( 1 5 . 2 )}$ & $\mathbf{( 1 1 . 9 )}$ & $\mathbf{( 1 . 7 )}$ & $\mathbf{( 2 4 . 8 )}$ & $\mathbf{( 4 1 . 0 )}$ \\
\hline
\end{tabular}

\section{Key:}

I. NA=Not Applicable. It applies to cases where the teacher is also the proprietor of the school or did not have an answer

IV. Fairly $S=$ Fairly Satisfied

II. Dissatisfy $=$ Dissatisfied

III. Fairly D=Fairly Dissatisfied

V. $\mathrm{F}=$ Frequency

VI. $\%=$ Percent

To collate the factors identified above as leading to satisfaction and dissatisfaction, teachers were asked to list five "things" that they liked and five that they did not like in their schools in order of priority.

From the teachers' responses, good interpersonal relationships had the highest frequency in all the five priority levels, followed by good working conditions. Salary and other benefits took third and fourth positions, respectively, as summarized in Table 4.

\begin{tabular}{|l|l|l|l|l|l|l|l|l|l|l|l|}
\hline \multirow{2}{*}{ Motivators } & \multicolumn{9}{|c|}{ P R I O R I T Y } \\
\cline { 2 - 14 } & \multicolumn{3}{|c|}{$\mathbf{1}$} & \multicolumn{2}{|c|}{$\mathbf{2}$} & \multicolumn{3}{|c|}{$\mathbf{4}$} & \multicolumn{2}{|c|}{$\mathbf{5}$} \\
\cline { 2 - 14 } & $\mathbf{F}$ & $\mathbf{( \% )}$ & $\mathbf{F}$ & $\mathbf{( \% )}$ & $\mathbf{F}$ & $\mathbf{( \% )}$ & $\mathbf{F}$ & $\mathbf{( \% )}$ & $\mathbf{F}$ & $\mathbf{( \% )}$ \\
\hline Good interpersonal relationship & 19 & 41.3 & 24 & 52.2 & 21 & 45.7 & 13 & 28.3 & 5 & 10.9 \\
& & & & & & & & & & \\
\hline Good working conditions & 9 & 19.6 & 11 & 24.0 & 8 & 17.4 & 7 & 15.2 & 4 & 8.7 \\
\hline Salary & 8 & 17.4 & 2 & 4.3 & 4 & 8.7 & 5 & 10.9 & 0 & 0.0 \\
\hline Other benefits & 3 & 6.5 & 3 & 6.5 & 1 & 2.2 & 7 & 15.2 & 1 & 2.2 \\
\hline Good management & 3 & 6.5 & 3 & 6.5 & 1 & 2.2 & 2 & 4.3 & 1 & 2.2 \\
\hline Personal convenience & 3 & 6.5 & 0 & 0.0 & 5 & 10.8 & 1 & 2.2 & 4 & 8.7 \\
\hline Workload & 0 & 0.0 & 0 & 0.0 & 1 & 2.2 & 1 & 2.2 & 4 & 8.7 \\
\hline No response & 1 & 2.2 & 3 & 6.5 & 5 & 10.8 & 10 & 21.7 & 27 & 58.6 \\
\hline
\end{tabular}

F= Frequency; \%= Percent

TABLE 4: Preschool Teachers' Identified Motivators 
The interpersonal relationships were comprised of teachers' relationship with children, parents, other teachers and the management committee or employer, with frequencies descending in that order. This meant that most preschool teachers were comfortable working with children and related well with other key players in the preschool Microsystems. Such a social environment was conducive to children's psychosocial development.

The working conditions, on the other hand, described both physical and social environments in the ECD centres. Qualities such as well-painted classrooms, adequate play area and clean compound facilitated teachers' contentment with the physical environment. Availability of equipment and the supply of teaching/learning materials also contributed to teachers' satisfaction with the physical environment.

The majority of the ECD teachers who were contented with the social environment were the study respondents drawn from coffee plantations whose workers were from different parts of Kenya. They expressed satisfaction with plantations managers' concern in their welfare, opportunity to be with people from different parts of the country and being allowed to grow crops on company farms. Further, some teachers found the conditions favorable because of fewer working hours (6 hours per day), and still others because of non-interference from management, which they put as, the "freedom to run the centres the way they want".

The amount of salary and increments received motivated only 6(13\%) teachers from 4 centres, while the others who cited salary as a motivator were happy about being paid on time and during the school holiday. The prioritized teacher motivators therefore, were consistent with the ranked levels. In addition to salary, fringe benefits that motivated preschool teachers included having a feeding programme from which they got a share of the snack or food, free tea, opportunity for in-service capacity building and free staffing housing.

Personal convenience and manageable workload were also found to motivate teachers though to a low degree. Personal convenience included being near home, being near a town or living in an area where basic necessities are affordable. Those who were in public preschools within primary schools were also motivated by an expectation that the Kenya Teachers Service Commission will eventually employ them. The few who were contented with the workload credited their position to manageable numbers of children in class.

Some findings of this study concur with others done in Kenya on teacher satisfaction. Makoti (2004), for example, found good conditions and terms of (private) preschool teachers' service to be a source of motivation. Karugu (1980) and Ngaroga (1985) specifically found working near home and relationships with pupils and other teachers to satisfy teachers in Kigumo Division and Nairobi Province respectively. Their findings are in harmony with the personal convenience and interpersonal relationships discussed above. While the two studies limited the motivating interpersonal relationships to teachers and pupils, this study found a more extensive range of the same. Further, Waithaka (2003) found good learning atmosphere, management and salary paid on time to be satisfiers among Thika Municipality preschool teachers. In addition to the above, this study identified community recognition for good work, manageable workload and fringe benefits as motivators of preschool teachers.

Among the things that de-motivated ECD teachers were low salary, poor physical working conditions, heavy workload, poor or inexistent terms of service and poor interpersonal relationships in that order, as shown in Table 5. 
Mary N. Ndani \& Elishiba N. Kimani

\begin{tabular}{|l|l|l|l|l|l|}
\hline \multirow{2}{*}{ De-motivator } & \multicolumn{5}{|c|}{ P R I O R I T Y } \\
\cline { 2 - 7 } & \multicolumn{1}{|c|}{$\mathbf{1}$} & \multicolumn{1}{|c|}{$\mathbf{2}$} & \multicolumn{1}{|c|}{$\mathbf{3}$} & \multicolumn{1}{c|}{$\mathbf{4}$} & \multicolumn{1}{c|}{$\mathbf{5}$} \\
\cline { 2 - 7 } & $\mathbf{F}(\mathbf{\%})$ & $\mathbf{F}$ & $\mathbf{F}$ & $\mathbf{F}$ & $\mathbf{F}$ \\
\hline Salary & $24(52.2)$ & 10 & 12 & $7(15.2)$ & $8(17.4)$ \\
\hline $\begin{array}{l}\text { Physical } \\
\text { working }\end{array}$ & $5(10.9)$ & 10 & 11 & $9(19.6)$ & 12 \\
\hline Workload & $5(10.9)$ & $6(13.0)$ & $4(8.7)$ & $7(15.2)$ & $4(8.7)$ \\
\hline $\begin{array}{l}\text { Other terms of } \\
\text { service }\end{array}$ & $1(2.2)$ & $4(8.7)$ & $4(8.7)$ & $5(10.9)$ & $2(4.3)$ \\
\hline $\begin{array}{l}\text { Interpersonal } \\
\text { relationships }\end{array}$ & $6(12.9)$ & $4(8.7)$ & $2(4.3)$ & $3(6.5)$ & $1(2.2)$ \\
\hline Others & $1(2.2)$ & $3(6.5)$ & $2(4.3)$ & $2(4.3)$ & $-(0.0)$ \\
\hline No response & $4(8.7)$ & $9(19.7)$ & $11(24.0)$ & $13(28.3)$ & $19(41.3)$ \\
\hline
\end{tabular}

NB: F= Frequency; $\%=$ Percent

TABLE 5: Preschool Teachers' De-motivators

Low salary emerged as the greatest de-motivator with 24(52.2\%) of the teachers placing it in the first priority and also having the highest percentage among all the other four levels of priority. Consistently, the amount of salary received was rated very low in the Likert Scale (see Table 3) with $21(45.7 \%)$ teachers being dissatisfied, $9(19.6 \%)$ fairly dissatisfied and only $2(4.3 \%)$ satisfied. Other factors related to low salary and contributing towards lack of motivation included parents' failure to pay fees on time and frequent withdrawal of children when parents lose their casual jobs in the ECD centre vicinity. These, coupled with delayed and irregular payment of salary, lack of salary increments, and failure to compensate for putting in extra time, further de-motivated the teachers.

Those who disliked the physical working conditions ranked poor and unmaintained facilities first, followed by inadequate outdoor play equipment, and lack of learning materials. This seemed to contradict the relative higher ranking of physical facilities as a motivator in the Likert Scale. The contradiction is, however only apparent as the two pieces of data served to emphasize the importance of physical facilities in teacher motivation. Thus, teachers appeared to like working in ECD centres with good facilities. Consequently, good working conditions ranked second in prioritization of the motivating factors just as in the de-motivating ones, with $9(19.6 \%)$ and $11(23.9 \%)$ teachers placing it in the first and second priority, respectively, among motivators, and 5(10.9\%) and 10(21.7\%) among de-motivators.

On the workload, teachers were de-motivated by failure to break for holidays, continuous admission of children up to the end of the school term and long working hours. Failure to break for holidays was reported by teachers in plantations. Those discontented with the "open" admission were mainly from privately sponsored preschools. They claimed that the practice made their planning very difficult because children were at different levels. To add to their disappointment, they were blamed when the lately admitted children did not perform well in interviews for entry into primary schools.

Concerning the workload, some teachers were unhappy about the number of working hours. These were mainly the teachers who arrived in ECD centres very early in the morning in order to receive children dropped by parents on their way to their work places. The teachers also waited for the parents to pick up children in the evening on their way home. Their dissatisfaction 
arose owing to the apparent lack of appreciation from their employers and lack of compensation for the extra time.

Other de-motivating terms of service included lack of letters of appointment, and by extension, lack of clear terms of employment, leave entitlement and conditions of termination. Employers' failure to consider teachers' welfare by denying them sick and maternity leaves, for example, was found to greatly de-motivate teachers. Having uncooperative parents and being harassed by management were also found to demotivate the teachers.

The foregoing findings are in agreement with other empirically based literature on teacher motivation in respect to de-motivating factors. In their study on the contribution of the quality of school facilities towards teacher attrition, Buckley, Schneider, \& Shang (2004) reviewed a number of such literatures. These studies showed that teachers were de-motivated by low salary. In some of them, for example Tye \& O'Brien (2002), teachers in the United Kingdom and California who were considering leaving the profession ranked salary considerations as the most important factor driving their decision.

Gritz \& Theobold (1996) also quoted by Buckley et al (2004), similarly found that compensation is the most important influence on the decision to remain in the profession for male and experienced female teachers. Dolton \& Klaauw (1995) also reportedly found higher teacher attrition rate in the U.K. to be driven by poor salary relative to non-teaching jobs. Studies done in Kenya (Ngaroga, 1985; Gatheru, 1987; Ngome, 2002 and Waithaka, 2003) all concur with these findings that teachers at all levels of the school system are de-motivated by low salary.

Furthermore, other teachers have been found to be dissatisfied with physical facilities. For example, a survey of K-12 teachers in Washington, D.C. cited in Buckley, et al (2004) found out that facility quality is an important predictor of the decision of teachers to leave their current position. To emphasize the importance of the physical environment, the above study cites Hanushek, Kain and Rivkin (2004) who asserted that teachers might be willing to take lower salaries in exchange for better working conditions. This statement may appear like an exaggeration, but its not, considering that the quality of school buildings affect the quality of teacher life and educational outcomes.

While the Kenyan teachers may not appreciate this, poor "Indoor Air Quality" (IAQ) reportedly leads to "sick building syndrome" which in turn increases student absenteeism, reduces student performance and affects both learners and teachers' health (Kennedy 2001; Leach, 1997; Smedje \& Norback 1999, among others, cited in Buckley, et al 2004).

Teacher dissatisfaction with the workload concurs with Rosenholtz \& Simpson (1990, cited by Buckley et al 2004) in their revelation that the burden of non-teaching obligations affects new teachers' commitment. Further, the study by Ngome (2002) identified high workload as one of the factors contributing towards high teacher attrition.

In summary, both aspects of the preschool microsystems investigated were found to be inadequate to support children's development. In $55 \%$ of the preschools, the physical environment was below average in suitability, and $52.2 \%$ of the teachers had below average levels of motivation. Teacher motivators were found to comprise mainly of work context factors. These included good interpersonal relationships, good working conditions, timely salary payment and being paid during the school holidays. Other benefits such as feeding in ECD centres, regular opportunities for in-service capacity building and good management were also mentioned. Teachers' de-motivators were also work context factors including: low salary, poor 
physical working conditions, high workload, unclear terms of service and poor interpersonal relationships.

Consequently, given the mandate of the Ministry of Education to manage all levels of education in Kenya, this study recommended that the Ministry not only improves but also harmonizes the terms and conditions of service of all ECD teachers in the country. Some of the required intervention may be in the form of intensified community participation, since it is communities that shape the job contexts. In particular, communities need to establish friendly relationships with ECD teachers and to appreciate the services they give to their children. The relationship between the level of community participation and that of the preschool microsystems (physical environment and teacher motivation), however, needs to be empirically established before recommending it as a remedy. 


\section{REFERENCES}

Black, J.K. and Puckett, M.B. (1996). The young child: Development from prebirth through age eight ( $2^{\text {nd }}$ ed.). Englewood Cliffs, New Jersey: Prentice Hall, Inc.

Buckley, J., Schneider, M., and Shang, Y. (2004). Organizing for effective early childhood programs and practices. Critical Issue, Cambridge: Harvard Family Research Project Posted by the National Clearinghouse for Educational Facilities Retrieved on March 19 2007, from $\underline{w w w . e d f a c i l i t i e s . o r g . ~}$

Essa, E.L. (2003). Introduction to early childhood education $\left(4^{\text {th }}\right.$ ed.). Canada: Thomson Delmar learning.

Gakii, M.C. (2003). Preschool teacher factors that influence the teacher child relationships in Miringa Mieru Divisions, Meru central district, Kenya. Unpublished M.Ed Thesis, Kenyatta University.

Gatheru, J. (1987). A study of factors that contribute to lack of satisfaction among primary school teachers. Unpublished M.Ed Thesis, University of Nairobi.

Herzberg, F. (1966). Work and Nature of Man. New York: World Publishing

Herzberg F., Mausner B. \& Snyderman B. (1959). The motivation to work. NewYork: JohnWiley \& Sons Inc.

Karagu, G. K. (1980). An investigation of job satisfaction-dissatisfaction among elementary school teachers and head-teachers in Nairobi, Kenya, and a comparison of their perceptions on fourteen selected job-factors from Herzberg's Two-Factor Theory. Unpublished PhD thesis, Kenyatta University.

Love, J. M., Ryler, P. and Faddis, B. (1992). Caring environments - Program quality in California's public funded child development programs. Staff: child ratio. (Report on the Legislatively mandated 1990-91 study). Portsmouth, RMC Research co-operative.

Makoti, N.M. (2005). Terms and conditions of service and their relationship to motivation of preschool teachers in Kwale District, Kenya. Unpublished MEd thesis, Kenyatta University.

Ministry of Education Science and Technology, (1999). The early childhood development project: Report of the ECD baseline survey on health and nutrition, community support grants and transition from preschool to primary school in G.O.K. Districts.

Ngaroga, J.M. (1985). A study of the factors that contribute to job satisfaction and dissatisfaction among the rural primary school teachers. Unpublished MEd Thesis, Kenyatta University.

Ng'asike, J.T. (2004). Teachers use of play as medium for bridging preschool children's mathematical experiences. A study of Kasarani Division, Nairobi, Kenya. Unpublished MEd Thesis, Kenyatta University.

Ngome, C.K. (2002). Quality of training and attrition of early childhood development teachers in Kenya. Manuscript submitted for publication.

Organization of African Unity, (1990). The African Charter on the Rights and Welfare of the Child. Nairobi, Kenya.

Orodho, J.A. (2004). Elements of education and social research methods. Nairobi: Masola Publishers.

Pipes P.L. and Trahms, N. (1993). Nutrition in infancy and childhood. Fifth Edition St. 
Louis Missouri: Mosby year book, Inc.

Read, K., Gardner, P. and Mahler, B. (1993). Early childhood programmes. Human relationships and learning. Florida: Harcourt Brace Jovanovich college publishers.

Republic of Kenya, (1998). Master plan on education and training 1997 - 2010. Nairobi: Jomo Kenyatta Foundations Printer.

United Nations (1989). Convention on the rights of the child. The General Assembly of the United Nations; $20^{\text {th }}$ November.

Waithaka, E.N. (2003). A study of preschool teacher job satisfaction by type of school sponsorship in Thika Municipality. Unpublished MEd Thesis, Kenyatta University. 